\title{
The role of eosinopenia in the diagnosis of bacterial infection in children
}

\author{
Çocuklarda bakteriyel enfeksiyon tanısında eozinopeninin rolü
}

\author{
Aysun Ata, Murat Anıl, Mehmet Helvacı
}

Gönderilme tarihi:18.11.2021

Kabul tarihi:18.02.2022

\begin{abstract}
Purpose: Number of eosinophils circulating in the blood decreased significantly after acute infections. Our aim in this study is to determine the role of eosinopenia in the diagnosis of bacterial infection in children and to compare it with other acute phase reactants.

Material and methods: Patients aged 0-14 years, who applied to İzmir Tepecik Training and Research Hospital Pediatrics Polyclinics and Pediatric Emergency Service between 01.01.2008 and 31.12.2008, whose hemogram and C-reactive protein were studied within the first 24 hours of admission were included in this study. The cases were screened according to the International Classification of diseases (ICD-10) diagnostic codes.

Results: Totally 1857 patients were included in the study. The patients were evaluated in 3 groups; 519 cases $(28 \%)$ with bacterial infection,356 cases (19.2\%) with viral infection, and 972 cases $(52.6 \%)$ in the control groups. The mean absolute eosinophil count in the bacterial infection group was $103.7 \pm 76.9 / \mathrm{mm}^{3}$, while it was $192.8 \pm 129.3 / \mathrm{mm}^{3}$, in the viral infection group, and this difference was statistically significant $(p<0.001)$. It was determined that the bacterial infection group had the highest C-reactive protein value, the lowest absolute eosinophil count, and the lowest absolute eosinophil count /white blood cell ratio, and this was statistically significant $(p<0.001)$. The parameter with the highest sensitivity was absolute eosinophil count/white blood cell with $73.7 \%$, and highest specificity was absolute eosinophil count with $82.4 \%$.

Conclusion: Absolute eosinophil count and absolute eosinophil count / white blood cell ratio as specific and sensitive markers in the diagnosis of bacterial infection in children, can be promising diagnostic parameters by providing ease of use in daily practice.
\end{abstract}

Key words: Childhood bacterial infections, eosinopenia, CRP.

Ata A, Anil M, Helvaci M. The role of eosinopenia in the diagnosis of bacterial infection in children. Pam Med J 2022;15:467-473.

Öz

Amaç: Akut enfeksiyonlardan sonra kanda dolaşan eozinofil sayısı önemli ölçüde azalır. Çocuklarda bakteriyel enfeksiyon tanısında eozinopeninin rolünü belirlemek ve diğer akut faz reaktanları ile karşılaştırmaktır.

Gereç ve yöntem: Bu çalışmaya Tepecik Eğitim ve Araştırma Hastanesi Çocuk Acil ve Çocuk Sağlığı Poliklinikleri'ne 01.01.2008-31.12.2008 tarihleri arasında başvuran, ilk 24 saat içinde hemogram ve C-reaktif protein çalışılan 0-14 yaş arası hastalar dahil edildi. Sisteme girilen hastalıkların ve sağlık sorunlarının uluslararası sınıflama sistemi (ICD-10) tanı koduna göre hastalar ayrıştırıldı.

Bulgular: Toplam 1857 hasta çalışmaya alındı. Hastalar 3 grupta değerlendirildiğinde; 519 (\%28) olgu bakteriyel enfeksiyon, $356(\% 19,2)$ olgu viral enfeksiyon ve $972(\% 52,6)$ olgu kontrol grubuna alındı. Bakteriyel enfeksiyon grubunda ortalama mutlak eozinofil sayısı 103,7 $\pm 76,9 \mathrm{hc} / \mathrm{mm}^{3}$ iken viral enfeksiyon grubunda 192,8 $\pm 129,3$ $\mathrm{hc} / \mathrm{mm}^{3}$ saptandı ve bu fark istatistiksel olarak anlamlıydı $(p<0,001)$. En yüksek C-reaktif protein, en düşük mutlak eozinofil sayısı ve en düşük mutlak eozinofil sayısı/beyaz kan hücresi (BK) oranı bakteriyel enfeksiyon grubunda saptandı ve bunun istatistiksel olarak anlamlı olduğu belirlendi $(p<0,001)$. En yüksek duyarlılığa sahip parametre $\% 73,7$ ile mutlak eozinofil sayısı/beyaz kan hücresi oranı ve en yüksek özgüllük \%82,4 ile mutlak eozinofil sayısı idi.

Sonuç: Çocuklarda bakteriyel enfeksiyon tanısında mutlak eozinofil sayısı ve mutlak eozinofil sayısı / beyaz kan hücresi oranı özgül ve duyarlı belirteçler olarak, günlük pratikte kullanabilme kolaylığı sağlayarak umut vaad eden tanısal parametreler olabilirler.

Anahtar kelimeler: Çocukluk çağı bakteriyel enfeksiyonları, eozinopeni, CRP.

Ata A, Anıl M, Helvacı M. Çocuklarda bakteriyel enfeksiyon tanısında eozinopeninin rolü. Pam Tıp Derg 2022;15:467-473.

Aysun Ata, M.D. Division of Pediatric Endocrinology, Department of Pediatrics, Adana City Training and Research Hospital, Adana, Turkey, e-mail: draysunkaya@gmail.com (https://orcid.org/0000-0002-6987-0923 (Corresponding Author)

MuratAnıl, Prof. Izmir Democracy University, Department of Pediatrics, Department of Pediatric Emrgency, Izmir, Turkey, e-mail: muratanil1969@ gmail.com (https://orcid.org/0000-0002-2596-4944)

Mehmet Helvacı, Prof. Izmir University of Health Sciences Tepecik Training and Research Hospital, Department of Pediatrics, Izmir, Turkey, e-mail: drmhelvaci54@gmail.com (https://orcid.org/0000-0001-2345-6789) 


\section{Introduction}

It was first discovered by Zappert in 1893 that the number of eosinophils circulating in the blood decreased significantly after acute infections [1]. Stress with bacterial, viral infections, and chemical irritants has also been shown to cause eosinopenia [2]. It is believed that the eosinopenic response seen in the early period of infection occurs as a result of rapid peripheral sequestration of circulating eosinophils [3]. The role of eosinopenia in certain specific infections has been investigated and there are many studies claiming that it can be used as an indicator of antibiotic response in the detection of early neonatal sepsis, differential diagnosis of bacterial viral meningitis, and early diagnosis of Covid-19 infection [3-7]. Our aim in this study is to determine the role of eosinopenia in the diagnosis of bacterial infection in children and to compare it with other acute phase reactants.

\section{Materials and methods}

Study was performed as a pediatric thesis in Izmir University of Health Sciences Tepecik Training and Research Hospital. Patients aged 0-14 years, who applied to Pediatrics Polyclinics and Pediatric Emergency Service between 01.01.2008 and 31.12.2008, whose hemogram and C-reactive protein (CRP) were taken within the first 24 hours of admission were included in this study. The cases were screened according to the International Classification of diseases (ICD) diagnostic codes, and those who were diagnosed with infection were analyzed. Those patients; who were diagnosed with a chronic disease and patients with asthma, atopic dermatitis or cortisol usage, that could affect the eosinophil value were not included.The bacterial infection group consisted of those who were found to have significant reproduction in culture (116 patients); or those who were found not to have significant reproduction in culture but who were considered and treated for bacterial infection according to clinical, radiology, and serology results (403 patients). In this group of patients, they were further classified according to their diagnosis; pneumonia, urinary tract infection, meningitis, osteomyelitis, septic arthritis, otitis media, bacterial upper respiratory tract infections, soft-tissue infection (cellulitis, erysipelas), sepsis, bacterial gastroenteritis, and other bacterial infections (brucellosis, intraabdominal abscess, retropharyngeal abscess, peritonitis). According to clinical and laboratory results, cases that were strongly believed to be viral, cases with PCR positivity and cases that were not prescribed antibiotics were included in the viral infection group. This group consisted of cases diagnosed with viral upper respiratory tract infection, influenza, acute bronchiolitis, aseptic meningitis, infectious mononucleosis, chickenpox, rubella, acute viral hepatitis, and acute viral gastroenteritis. Finally, the following were included in the control group; healthy children who visited the pediatric outpatient clinics for routine examination but were not diagnosed with infection and who had a hemogram for screening purposes and who were followed up with the diagnosis of epilepsy or short stature.

Cases with axillary body temperature of $38.5^{\circ} \mathrm{C}$ and above at the admission were considered to have fever, and those with body temperature below $38.5^{\circ} \mathrm{C}$ were considered to have no fever. The data was evaluated for statistical analysis by using SPSS for Windows 14.0. Numerical data were expressed with arithmetic mean and standard deviation (mean $\pm S D$ ), median, minimum and maximum values, while non-numerical data were indicated with percentage (\%). One-way ANOVA test was used to compare more than two parametric data. When this test showed a significant difference, Post-hoc (Tukey and Bonferroni) tests determined which parameter the significance was caused by. Student-t test was used to compare the two parametric data. $P<0.05$ was considered statistically significant. The diagnostic characteristics of the tests were investigated using the ROC (receiver operating characteristic) analysis technique, which summarizes the validity coefficient of the test and provides an inclusive diagnostic accuracy index. Sensitivity, specificity, cut point and ROC curve analyses were performed with the Medcalc statistical program.

Ethics committee approval was obtained from Izmir University of Health Sciences Tepecik Training and Research Hospital as Pediatric thesis.

\section{Results}

A total of 1847 patients were included in the study. The patients were evaluated in 3 groups; 519 cases $(28.1 \%)$ with bacterial infection, 356 cases $(19.3 \%)$ with viral infection, and 
972 cases $(52.6 \%)$ in the control groups. The average age of all patients was 19.8 (0-174.4) months (further demographic characteristics are given in Table 1). A pathogen was detected in culture in $116(22.3 \%)$ of the patients diagnosed with bacterial infection. The highest diagnosis rate in patients in the bacterial infection group was pneumonia (33.7\%) (Table 2). In the evaluation of laboratory results of the groups, it was determined that the bacterial infection group had the highest CRP value, the lowest absolute eosinophil count (aEC), and the lowest aEC/WBC (white blood cell) value, and this was statistically significant $(p<0.001)$ (Table 3$)$. When post-hoc Bonferroni test was performed, all groups differed significantly from each other for parameters: aEC, aEC/WBC, WBC, and aNC. Of the cases diagnosed with bacterial infection $386 \quad(74.3 \%)$ received inpatient treatment. Hospitalized (inpatient) patients were found to have a significantly low aEC compared to non-hospitalized patients $(p<0.001)$ (Table
4). In viral infection group145 patients (44.5\%) were hospitalized.

When the acute phase responses used in the diagnosis of bacterial infection were compared, the sensitivity of WBC, absolute neutrophil count (aNC), aEC, aEC/WBC, CRP, and erytrocyte sedimentation rate (ESR) was determined respectively as $62.8 \%, 63.5 \%, 61.4 \%, 73.7 \%$, $72.7 \%$, and $62.7 \%$; and the specificities as $62.5 \%, 70.2 \%, 82.4 \%, 72.7 \%, 75.6 \%$, and $71.8 \%$. It was found that the parameter with the highest sensitivity was aEC/WBC. The parameter with the highest specificity was aEC (Table 5). The cut-off point for the aEC was 50 cell $/ \mathrm{mm} 3$, and $1.1 \% \mathrm{aEC} / \mathrm{WBC}$ for diagnosis of bacterial infections. When ROC curve analysis was used to predict bacterial infection, the two largest area under curves were belonging to CRP and aEC/WBC (CRP: 0.800 units $^{2}$; aEC: 0.783 units $^{2}$ ). The ROC analysis is given in Figure 1.

Table 1. Demographic and clinical characteristics of the patients

\begin{tabular}{|c|c|c|c|c|c|}
\hline & & $\begin{array}{l}\text { Bacterial Infection } \\
\mathrm{N}=519\end{array}$ & $\begin{array}{l}\text { Viral Infection } \\
\mathrm{N}=356\end{array}$ & $\begin{array}{l}\text { Control } \\
\mathrm{N}=972\end{array}$ & $p$ \\
\hline \multicolumn{2}{|c|}{ Age (months)(min-max) } & $20.8(0-174.4)$ & $12.1(0-170.8 \%)$ & $21.7(0-168.9)$ & 0.007 \\
\hline Gender & Girl & $248(47.8 \%)$ & $145(40.8 \%)$ & $457(47 \%)$ & 0.082 \\
\hline n (\%) & Boy & $271(52.2 \%)$ & $210(59.2 \%)$ & $515(53 \%)$ & \\
\hline Hospitalization $\mathbf{n}$ & Yes & $388(74.8 \%)$ & $158(44.5 \%)$ & & $<0.001$ \\
\hline$(\%)$ & No & $131(25.2 \%)$ & $197(55.5 \%)$ & & \\
\hline Fever & Yes & $373(71.9 \%)$ & $99(27.7 \%)$ & & $<0.001$ \\
\hline n (\%) & No & $146(28.1 \%)$ & $257(72.3 \%)$ & & \\
\hline
\end{tabular}

Table 2. Distribution of patients diagnosed with bacterial infection

\begin{tabular}{lll}
\hline Diagnosis & $\mathbf{n}$ & \% \\
\hline Pneumonia & 174 & 33.7 \\
Urinary tract infection & 112 & 21.7 \\
Meningitis & 44 & 8.5 \\
Osteomyelitis & 10 & 1.9 \\
Septic arthritis & 11 & 2.1 \\
Bacterial upper respiratory tract infection & 61 & 11.8 \\
Cellulitis & 13 & 2.5 \\
Sepsis & 56 & 10.8 \\
Bacterial gastroenteritis & 10 & 1.9 \\
Other bacterial infections & 26 & 5.0 \\
Total & 519 & 100 \\
\hline
\end{tabular}


Table 3. Comparison of laboratory values of groups

\begin{tabular}{|c|c|c|c|c|}
\hline & $\begin{array}{l}\text { Bacterial Infection } \\
n=519\end{array}$ & $\begin{array}{l}\text { Viral Infection } \\
n=356\end{array}$ & $\begin{array}{l}\text { Control } \\
n=972\end{array}$ & $p$ \\
\hline $\begin{array}{l}\text { WBC }\left(/ \mathrm{mm}^{3}\right) \\
(\text { Mean } \pm S D)\end{array}$ & $13223 \pm 7304$ & $10776 \pm 4512$ & $9723 \pm 4398$ & $<0.001$ \\
\hline 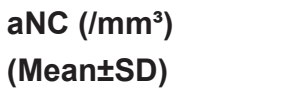 & $8348 \pm 6362$ & $5330 \pm 3575$ & $4619 \pm 3149$ & $<0.001$ \\
\hline $\begin{array}{l}\text { aEC }\left(/ \mathrm{mm}^{3}\right) \\
\text { median (min-max) }\end{array}$ & $30(0-1500)$ & $100(0-1700)$ & $200(0-2900)$ & $<0.001$ \\
\hline $\begin{array}{l}(\mathrm{aEC} / \mathrm{WBC})^{*} \times 100 \\
\text { median (min-max) }\end{array}$ & $0.22(0-14.7)$ & $1.33(0-19.1)$ & $2.21(0-50.01)$ & $<0.001$ \\
\hline $\begin{array}{l}\text { CRP (mg/dL) } \\
\text { median (min-max) }\end{array}$ & $1.5(0-54.9)$ & $0.5(0-12.5)$ & & $<0.001$ \\
\hline $\begin{array}{l}\text { ESR (mm/hour) } \\
\text { median (min-max) }\end{array}$ & $26(3-41)$ & $16(2-68)$ & & $<0.001$ \\
\hline
\end{tabular}

*WBC: white blood cells, aNC: absolute neutrophil count, aEC: absolute eosinophil count aEC/WBC: absolute eosinophil count/white blood cell, CRP: C-reactive protein,

ESR: erytrocyte sedimentation rate, SD: standard deviation

Table 4. Comparison of inpatients' and outpatients' laboratory for bacterial infections

\begin{tabular}{|c|c|c|c|}
\hline $\begin{array}{l}\text { Acute phase proteins } \\
\text { (Mean } \pm \text { SD) }\end{array}$ & $\begin{array}{l}\text { Inpatients } \\
\mathrm{n}=386\end{array}$ & $\begin{array}{l}\text { Outpatients } \\
n=133\end{array}$ & $p$ \\
\hline $\begin{array}{l}\text { WBC }\left(/ \mathrm{mm}^{3}\right) \\
(\text { Meantsd) }\end{array}$ & $13511 \pm 6990$ & $12392 \pm 8116$ & 0.127 \\
\hline $\begin{array}{l}\text { aNC }\left(/ \mathrm{mm}^{3}\right) \\
(\text { Meantsd) }\end{array}$ & $8792 \pm 6336$ & $7064 \pm 6285$ & 0.007 \\
\hline $\begin{array}{l}\mathrm{aEC}\left(/ \mathrm{mm}^{3}\right) \\
\text { median (min-max) }\end{array}$ & $20(0-1500)$ & $90(0-1300)$ & $<0.001$ \\
\hline $\begin{array}{l}(\mathrm{aEC} / \mathrm{WBC})^{*} \times 100 \\
\text { median }(\text { min-max })\end{array}$ & $0.11(0-14.7)$ & $0.92(0-11.5)$ & $<0.001$ \\
\hline $\begin{array}{l}\text { CRP }(\mathrm{mg} / \mathrm{dL}) \\
\text { median (min-max) }\end{array}$ & $1.5(0-54.9)$ & $0.71(0-29.2)$ & 0.001 \\
\hline $\begin{array}{l}\text { ESR (mm/hour) } \\
\text { median (min-max) }\end{array}$ & $38.6 \pm 30.3$ & $25.7 \pm 19.6$ & $<0.001$ \\
\hline
\end{tabular}

*WBC: White blood cells, aNC: absolute neutrophil count, aEC: absolute eosinophil count aEC/WBC: absolute eosinophil count/white blood cell, CRP: C-reactive protein

ESR: erytrocyte sedimentation rate, SD: standard deviation

Table 5. Comparision of ROC curves for diagnosis of bacterial infections

\begin{tabular}{lllll}
\hline Acute Phase reactants & $\begin{array}{l}\text { AUC } \\
\left(\text { Unit }^{2}\right)\end{array}$ & Cut off & $\begin{array}{l}\text { Sensitivity } \\
(\%)\end{array}$ & Specificity (\%) \\
\hline WBC $\left(/ \mathrm{mm}^{3}\right)$ & 0.649 & 10000 & 62.8 & 62.5 \\
aEC $\left(/ \mathrm{mm}^{3}\right)$ & 0.759 & 50 & 61.4 & 82.4 \\
$(\mathrm{aEC} / \mathrm{WBC})^{*} 100$ & 0.783 & 1.1 & 73.7 & 72.7 \\
CRP $(\mathrm{mg} / \mathrm{dL})$ & 0.800 & 0.50 & 72.7 & 75.6 \\
ESR (mm/hour) & 0.717 & 20 & 62.7 & 71.8 \\
\hline
\end{tabular}

${ }^{*}$ AUC: Area under curve, WBC: White blood cells, aEC: absolute eosinophil count aEC/WBC: absolute eosinophil count/white blood cell, CRP: C-reactive protein ESR: erytrocyte sedimentation rate 


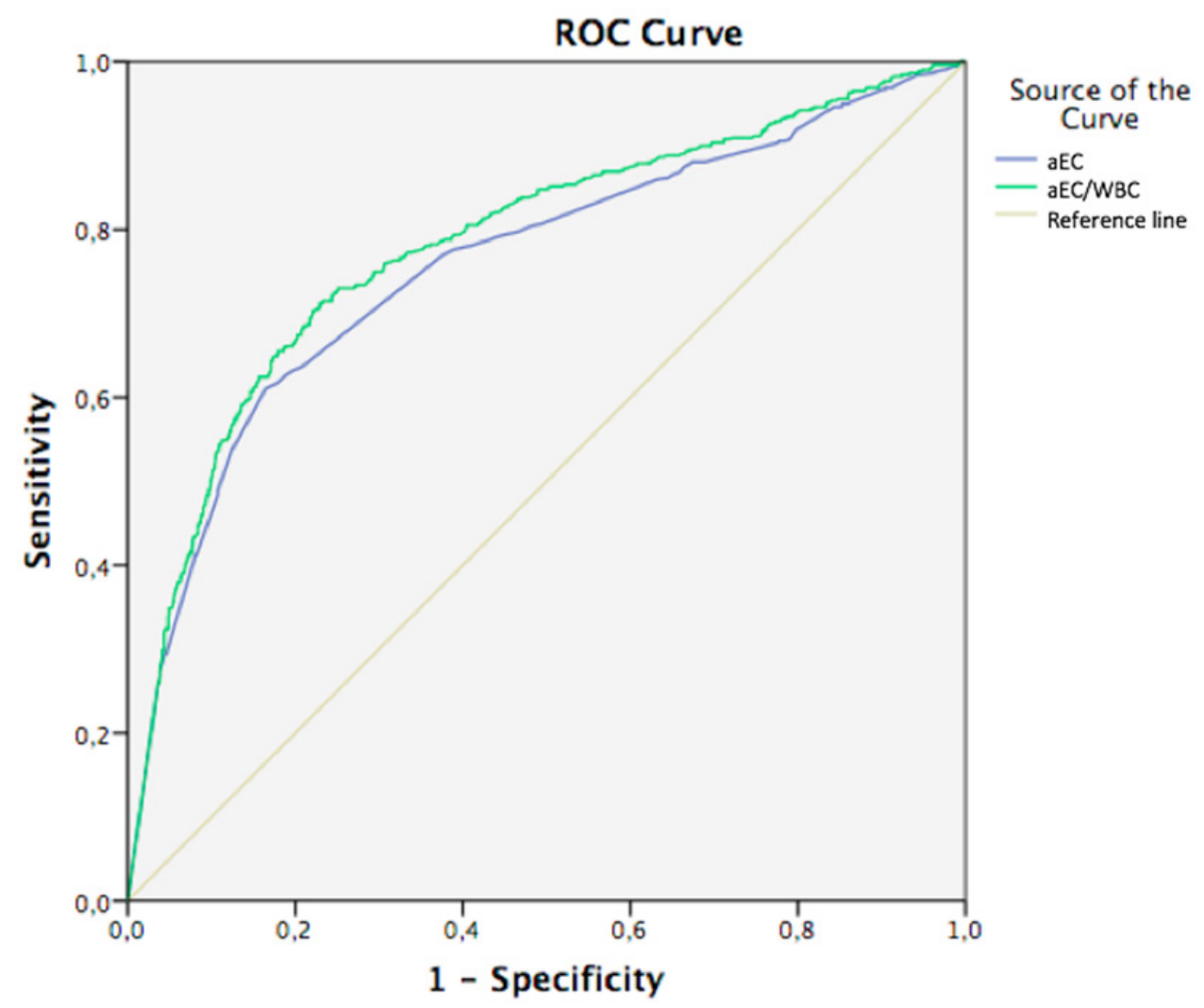

Figure 1. The ROC curve of the decrease in the absolute eosinophil count $(\mathrm{aEC})$ and $\mathrm{aEC} / \mathrm{WBC}$ ratio in the diagnosis of bacterial infection

\section{Discussion}

The normal value of eosinophils is accepted as $1-3 \%$ of circulating leukocytes [3]. Eosinopenia has long been forgotten and has not been used clinically. But recent studies have demonstrated the role of eosinopenia in bacterial infections and in the diagnosis of sepsis [8,9]. In our study, we found that eosinophil values were lower in all infectious diseases than the healthy control group. Other studies evaluating infections, such as sepsis, and meningitis similarly show low aECs in infected persons [10-12]. A study conducted by Karakonstantis and his colleagues examined 271 patients diagnosed with infection. The specificity was determined as $90 \%$ when eosinopenia limit value was taken $10 / \mu \mathrm{L}$ in patients. Eosinophil values were low in patients who died, while aEC rose rapidly in the group of patients who recovered [13]. Lavoignet and colleagues, examined adult emergency room visits and compared 466 patients diagnosed with bacterial infections with a control group. The specificity was determined as $100 \%$ when the eosinophil limit value was taken $<10 / \mathrm{mm}^{3}$ [14]. In our study, similar to the studies of Karakonstantis and Lavoignet, it was shown that the parameter with the highest specificity was $\mathrm{aEC}$ and the parameter with the highest sensitivity was $a E C / W B C$. This suggests that eosinophil value and $a E C / W B C$ are valuable parameters for both diagnosis and disease exclusion. However, no studies have been found in the literature comparing acute phase reactants with $\mathrm{aEC} / \mathrm{WBC}$, indicating that this issue needs to be studied further.

In a study conducted by Outh and colleagues, 121 patients were examined and 57 of them were positive for Covid-19. The sensitivity of eosinopenia in diagnosing Covid-19 was $89.5 \%$, and the specificity was $78.1 \%$ [7]. Although detection of low aEC in patients with a diagnosis of Covid-19 created the suspicion that the number of eosinophils may also decrease in severe viral infections as an acute stress response, and that this parameter alone may not be sufficient in the differentiation of bacterialviral infection. The study of Debray and his colleagues has shown otherwise [5]. Debray compared cases of pediatric bacterial meningitis with cases of viral meningitis. While the lowest 
aEC was found in the patients hospitalized in the intensive care unit, the $\mathrm{aEC}$ was found to be much lower in the bacterial meningitis patients than in the viral meningitis group. This shows that this inexpensive parameter can be used together with other infection markers in bacterial-viral infection differentiation. But there are no clear limits for the differantiation of these diseases. In our study, when we compared bacterial infections and viral infections, we found significant differences in $\mathrm{aEC}$ and $\mathrm{aEC} /$ WBC, but we could not give a significant limit value. We believe that more work needs to be done on this issue.

One of the strengths of our study is the large number of patients and the largest study investigating eosinopenia in the pediatric age group. Its limitation is that patients are usually selected from hospitalized patients, which leads to the bias of taking clinically more severe patients into the study. In our study, aEC was taken within the 24 hours of the admission and the follow-up data was not taken. But recording aEC in the follow-up suggests that it can be studied as a new parameter as a prognostic indicator.

As a result, in diagnosing bacterial infection in children and distinguishing it from viral infection, the number of eosinophils should be taken into account as a parameter that is easy, not imposing additional financial burdens, and giving results in a short period of time. We believe that using the absolute number of eosinophils and the aEC/WBC ratio, which many doctors ignore, will actually promising in diagnosing infections.

Limitations: The patients included in the study were chosen from a hospital operating program. Diagnosis were not made by a single physician and this may lead to physical examination findings not standardized. Patients were usually selected from hospitalized patients, which may have lead to the bias of taking clinically more severe patients into the study. High number of hospitalisation also may have altered laboratory values. The other limitation is the retrospective nature of the study and all the bacterial and viral infections were not proven.

Conflict of interest: None of the authors have any potential conflicts of interest associated with this research.

\section{References}

1. Bass DA. Behavior of eosinophil leukocytes in acute inflammation. II. Eosinophil dynamics during acute inflammation. J Clin Invest 1975;56:870-879. https:// doi.org/10.1172/JCl108166

2. Bass DA, Gonwa TA, Szejda P, Cousart MS, DeChatelet LR, McCall CE. Eosinopenia of Acute Infection. J Clin Invest 1980;65:1265-1271. https://doi.org/10.1172/ JCl109789

3. Gil H, Magy N, Mauny F, Dupond JL. Value of eosinopenia in inflammatory disorders: an "old" marker revisited. Rev Med Interne 2003;24:431-435. https:// doi.org/10.1016/s0248-8663(03)00138-3

4. Abidi K, Khoudri I, Belayachi J, et al. Eosinopenia is a reliable marker of sepsis on admission to medical intensive care units. Crit Care 2008;12:59. https://doi. org/10.1186/cc6883

5. Debray A, Nathanson S, Moulin F, Salomon J, Davido B. Eosinopenia as a marker of diagnosis and prognostic to distinguish bacterial from aseptic meningitis in pediatrics. Eur $\mathrm{J}$ Clin Microbiol Infect Dis 2019;38:1821-1827. https://doi.org/10.1007/s10096019-03614-y

6. Tanni F, Akker E, Zaman MM, Figueroa N, Tharian B, Hupart KH. Eosinopenia and COVID-19. J Osteopath Med 2020;120:504-508. https://doi.org/10.7556/ jaoa.2020.091

7. Outh $R$, Boutin $C$, Gueudet $P$, Suzuki $M$, Saada $M$, Aumaître H. Eosinopenia $<100 / \mu \mathrm{L}$ as a marker of active COVID-19: an observational prospective study. J Microbiol Immunol Infect 2021;54:61-68. https://doi. org/10.1016/j.jmii.2020.12.005

8. Smithson A, Perelló R, Nicolas JM. Is eosinopenia a reliable marker of sepsis? Crit Care 2009;13:409. https://doi.org/10.1186/cc7877

9. Wilar R. Diagnostic value of eosinopenia and neutrophil to lymphocyte ratio on early onset neonatal sepsis. Korean J Pediatr 2019;62:217-223. https://doi. org/10.3345/kjp.2018.06723

10. Xia Z. Eosinopenia as an early diagnostic marker of COVID-19 at the time of the epidemic. EClinicalMedicine 2020;23:100398. https://doi. org/10.1016/j.eclinm.2020.100398

11. Garnacho Montero J, Huici Moreno MJ, Gutiérrez Pizarraya A, et al. Prognostic and diagnostic value of eosinopenia, C-reactive protein, procalcitonin, and circulating cell-free DNA in critically ill patients admitted with suspicion of sepsis. Crit Care Lond Engl 2014;18:116. https://doi.org/10.1186/cc13908

12. Soni M. Evaluation of eosinopenia as a diagnostic and prognostic indicator in COVID-19 infection. Int $\mathrm{J}$ Lab Hematol 2021;43:137-141. https://doi.org/10.1111/ ijlh.13425 
13. Karakonstantis S, Gryllou N, Papazoglou G, Lydakis C. Eosinophil count (EC) as a diagnostic and prognostic marker for infection in the internal medicine department setting. Rom J Intern Med 2019;57:166-174. https:// doi.org/10.2478/rjim-2018-0039

14. Lavoignet $\mathrm{CE}$, Le Borgne $\mathrm{P}$, Slimani $\mathrm{H}$, et al. Relevance of eosinopenia as marker of sepsis in the emergency department. Rev Médecine Interne 2016;37:730-734. https://doi.org/10.1016/j.revmed.2016.02.018

Ethics approval: Ethics committee approval was obtained from Izmir University of Health Sciences Tepecik Training and Research Hospital as a Pediatric thesis.

\section{Author contributions}

A.A. and M.A. designed the study; A.A. and M.A. collected data; M.A. and M.H. analysed data; A.A., M.A. and M.H. wrote the manuscript. All authors read and approved the final manuscript.

Presented as an oral presentation at the 3rd National Health Services Symposium. 